\title{
NOVEL CYANINE DYES AS POTENTIAL AMYLOID PROBES: A FLUORESCENCE STUDY
}

\author{
U. Tarabara ${ }^{1}$, K. Vus ${ }^{1}$, A. Kurutos ${ }^{2}$, O. Ryzhova ${ }^{1}$, V. Trusova ${ }^{1}$, G. Gorbenko ${ }^{1}$, \\ N. Gadjev ${ }^{2}$, T. Deligeorgiev ${ }^{2}$ \\ ${ }^{I}$ Department of Nuclear and Medical Physics, V.N. Karazin Kharkiv National University \\ 4 Svobody Sq., Kharkiv, 61022, Ukraine \\ ${ }^{2}$ Faculty of Chemistry and Pharmacy, Sofia University, "St. Kliment Ohridski', 1 \\ blv. J. Bourchier, Sofia, 1164, Bulgaria \\ e-mail:uliana.tarabara@gmail.com \\ Received February 22, 2018
}

The applicability of the novel heptamethine cyanine dyes AK7-5 and AK7-6 to the detection and characterization of one-dimensional protein aggregates (amyloid fibrils) associated with numerous pathologies has been evaluated using the method of fluorescence spectroscopy. It was found that both the monomeric and aggregated forms of these dyes can bind to amyloidogenic protein lysozyme, but the concomitant changes in the electronic structure of H-aggregates render them capable of fluorescing. The growth of the hypsochromic bands with negligible changes of the monomeric peaks induced by the native protein and the opposite effects induced by the lysozyme fibrils suggest that the native lysozyme has more binding sites for the dye aggregates than fibrillar protein, while the fibril grooves represent specific binding site for the dyes monomers. The observed spectral behavior of the cyanine dyes, viz. significant distinctions in the fluorescence responses produced by the monomeric and fibrillar forms of lysozyme, suggest the possibility of recruiting these compounds as fluorescent amyloid markers along with the classical amyloid marker Thioflavin T.

KEYWORDS: Heptamethine cyanine dyes, amyloid marker, H-aggregates, fluorescence, lysozyme, amyloid fibrils

\author{
НОВІ ЦАНІНОВІ БАРВНИКИ ЯК ПОТЕНЦІЙНІ АМІЛОЇДНІ ЗОНДИ: \\ ФЛУОРЕСЦЕНТНЕ ДОСЛІДжЕННЯ
У. Тарабара
${ }^{1}$, К. $_{\text {Вус }}{ }^{1}$, А. Курутос
, О. Рижова \\ ${ }^{l}$ Кафедра ядерної та медичної фізики, Харківський начіональний університет імені В.Н. Каразіна \\ пл. Свободи 4, Харків, 61022, Украӥна \\ ${ }^{2}$ Факультет хімії і фармації, Софійський університет, Софія, 1164, Болгарія
}

За допомогою методу флуоресцентної спектроскопії проведена оцінка можливості використання нових гептаметинових ціанінових барвників AK7-5 та АK7-6 для детектування і характеризації одномірних білкових агрегатів (амілоїдних фібрил), пов'язаних із розвитком численних патологій. Показано, що мономерна та агрегована форми цих барвників можуть зв'язуватись з амілоїдогенним білком лізоцимом, а супутні зміни в електронній структурі Н-агрегатів надають їм здатності флуоресціювати. Зростання гіпсохромної смуги, поряд 3 незначними змінами мономерного піка, індуковані нативним білком, і протилежні ефекти, викликані фібрилами лізоциму, дозволяють припустити, шо нативний лізоцим має більшу кількість сайтів зв'язування для агрегатів барвника, ніж фібрилярна форма білка, в той час як жолобки фібрил являють собою специфічні сайти зв'язування для мономерів барвника. Спостережувана спектральна поведінка ціанінів, а саме значні відмінності флуоресцентних відповідей, що викликані мономерною та фібрилярною формами лізоциму, свідчать про можливість застосування цих сполук в якості флуоресцентних амілоїдних маркерів, поряд 3 класичним маркером Тіофлавіном Т.

КЛЮЧОВІ СЛОВА: Гептаметинові ціанінові барвники, амілоїдний маркер, Н-агрегати, флуоресценція, лізоцим, амілоїдні фібрили

\section{НОВЫЕ ЦИАНИНОВЫЕ КРАСИТЕЛИ КАК ПОТЕНЦИАЛЬНЫЕ АМИЛОИДНЫЕ ЗОНДЫ: ФЛУОРЕСЦЕНТНОЕ ИССЛЕДОВАНИЕ

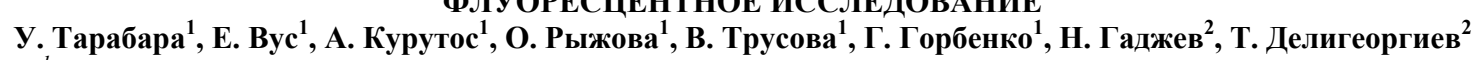 \\ ${ }^{1}$ Кафедра ядерной и медицинский физики, Харьковский начиональный университет имени В.Н. Каразина пл. Свободы 4, Харьков, 61022, Украина \\ ${ }^{2}$ Факультет химии и фармачии, Софийский университет, София, 1164, Болгария}

С помощью метода флуоресцентной спектроскопии проведена оценка возможности использования новых гептаметиновых цианиновых красителей AK7-5 и AK7-6 для детектирования и характеризации одномерных белковых агрегатов (амилоидных фибрилл), связанных с развитием множества патологий. Показано, что мономерная и агрегированная формы этих красителей могут связываться с амилоидогенным белком лизоцимом, а сопутствующие изменения в электронной структуре Н-агрегатов делают их способными флуоресцировать. Рост гипсохромной полосы, наряду с незначительными изменениями мономерного пика, индуцируемые нативным белком, и противоположные эффекты, вызванные фибриллами лизоцима, позволяют предположить, что нативный лизоцим обладает большим количеством сайтов связывания для агрегатов красителя, чем фибриллярная форма белка, в то время как желобки фибрилл представляют собой специфические сайты связывания для мономеров красителя. Наблюдаемое спектральное поведение цианинов, а именно значительные различия флуоресцентных ответов, вызванных мономерной и фибриллярной формами лизоцима, свидетельствует о возможности применения этих соединений в качестве флуоресцентных амилоидных маркеров, наряду с классическим маркером Тиофлавином Т. 
КЛЮЧЕВЫЕ СЛОВА: Гептаметиновые цианиновые красители, амилоидный маркер, Н-агрегаты, флуоресценция, лизоцим, амилоидные фибриллы

The accumulation of the highly ordered protein aggregates, amyloid fibrils, in various tissues and organs is associated with a variety of human diseases, including Alzheimer's, Parkinson's disease, systemic amyloidosis, type II diabetes, etc [1]. Amyloid fibrils represent highly ordered one-dimensional protein aggregates up to several micrometers in length and several nanometers in width, consisting of cross- $\beta$-structure core, in which $\beta$-sheets are oriented along the long axis of fibril [2-4]. One of the most powerful approaches to the detection of amyloid fibrils is based on the use of fluorescent dyes [5]. The classical amyloid markers are Thioflavin T and Congo Red [6-10], whose association with $\beta$-sheet structure of amyloid fibrils is accompanied by a substantial increase of fluorescence intensity and significant shifts in the absorption, fluorescent and excitation spectra [11-13]. Nevertheless, these well-known dyes have some drawbacks, among which are low result reproducibility and poor specificity to amyloid fibrils, the propensity for binding to $\alpha$-helical polypeptide fragments, etc. [14,15]. In view of this, extensive research efforts are currently focused on looking for the more effective amyloid-specific flurophores.

Near-infrared (NIR) cyanine dyes, a wide class of organic molecules with unique photophysical properties, such as high extinction coefficients, high fluorescence quantum yield and long-wavelength absorption and fluorescence maxima [16-18]. They have found numerous applications in different areas including optoelectronics, laser technologies, bioanalytics, photoelectrochemistry, etc. [19-22]. Due to their advantageous spectral characteristics cyanines have been employed in biomedical research and diagnostics as non-covalent labels for detection of proteins, nucleic acids, lipids and strong oxidizing agents [23-27]. Remarkably, cyanine dyes have been also successfully applied to the identification of amyloid fibrils and inhibition of their growth [28-32]. The advantages of these compounds over the classical amyloid marker Thioflavin $\mathrm{T}$ are fluorescence and absorption in the NIR region, high reproducibility of the results and more pronounced changes in fluorescence and absorbption spectra upon fibril binding [33].

Most cyanine dyes are known to aggregate in an aqueous solution and show the changes in the emission and absorption spectra with respect to the monomeric species. These assemblies are stabilized by van der Waals, H-bonding, hydrophobic, electrostatic, steric and stacking intermolecular interactions [34,35]. The aggregates that exhibit hypsochromically shifted band (H-band) in their absorption/emission spectrum are called $\mathrm{H}$-aggregates, while J-aggregates display bathochromic shift relative to the monomer band [36]. This behavior was explained by the exciton theory, that considers the individual dye molecule as a point dipole [37]. In the first approximation, taking up only two dye molecules, the interaction between their transition dipoles splits the exciton state of the aggregate into two levels [38]. H-dimers with sandwich-type arrangement (or plane-to-plain staking) during self-assembly transit to an upper energy level, resulting in the short-wavelength shift of the absorption maximum. The head-to-tail arrangement (end-toend stacking) of J-dimers is coupled with the transition into lower state with respect to the monomer species, thus exhibiting the long-wavelength shifted absorption band. The structural packing of the dye molecules in the aggregate is described by the slippage angle $\alpha$ defined as the angle between the direction of any one of the parallel molecules and long axis passing through the centers of the aggregated molecules. In particular, when $\alpha=90^{\circ}$ the molecules are in a parallel orientation, while when $\alpha=0^{\circ}$ a linear molecular orientation is observed [39]. In a general case, the slippage angles ranging from $0^{\circ}$ to $32^{\circ}$ correspond to J-aggregates, while the angles $\left\{32^{\circ}-90^{\circ}\right\}$ are observed for H-aggregates [17].

The aim of the present study is to assess the amyloid-sensing propensity of the two newly synthesized nearinfrared cyanine heptamethine dyes, AK7-5 and AK7-6. To this end, we compared the fluorescence responses of the examined dyes in the presence of the native and fibrillar lysozyme. Lysozyme is a well-characterized multifunctional protein with bactericidal, antitumor and immunomodulatory activitues. The mutants of human lysozyme (I56T, F57I, W64R, D67H) are prone to pathological fibrillization implicated in the molecular etiology of familial nonneuropathic systemic amyloidosis, a disease affecting kidney, liver and spleen [40].

\section{EXPERIMENTAL SECTION}

Materials. Hen egg white lysozyme (Lz) was obtained from Sigma (St. Louis, MO, USA). Cyanine probes AK7-5 and AK7-6 (Fig. 1) were synthesized in the University of Sofia, Bulgaria, as described previously [41]. Stock solutions of AK7-5 and AK7-6 were prepared by dissolving the dyes in dimethylsulfoxide (DMSO), then diluted by 5 mM sodium phosphate buffer ( $\mathrm{pH}$ 7.4) and used for spectroscopic measurements. The concentration of the dyes was determined spectrophotometrically, using the extinction coefficients $\varepsilon_{808}^{D M S O}=0.197 \mu \mathrm{M}^{-1} \mathrm{~cm}^{-1}$ and $\varepsilon_{814}^{D M S O}=0.209 \mu \mathrm{M}^{-1} \mathrm{~cm}^{-1}$ for AK7-5 and AK7-6, respectively.

Preparation of amyloid fibrils. Amyloid fibrils were obtained from the egg yolk lysozyme by the protein incubation in $10 \mathrm{mM}$ glycine buffer at $\mathrm{pH} 2$ and $60{ }^{\circ} \mathrm{C}$ for 14 days [41]. Protein concentration in the stock solution was $10 \mathrm{mg} / \mathrm{ml}$. The working solutions of the native and fibrillar lysozyme were prepared in $5 \mathrm{mM}$ sodium phosphate buffer ( $\mathrm{pH}$ 7.4). Hereafter, the native and fibrillar protein forms are designated as LzN and LzF, respectively.

Fluorescence measurements. Fluorescence spectra of AK7-5 and AK7-6 were recorded with the spectrofluorimeter Shimadzu RF-6000 (Japan) at $25^{\circ} \mathrm{C}$ using $5 \mathrm{~nm}$ excitation and emission slit widths. The excitation and emission wavelengths are indicated in the legends to figures. 


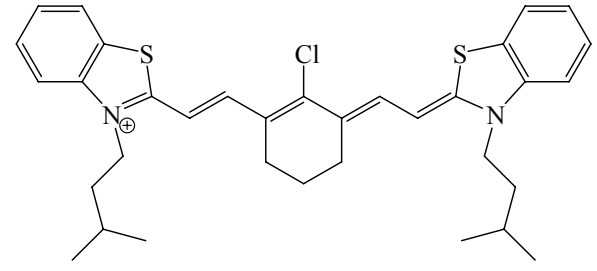

a

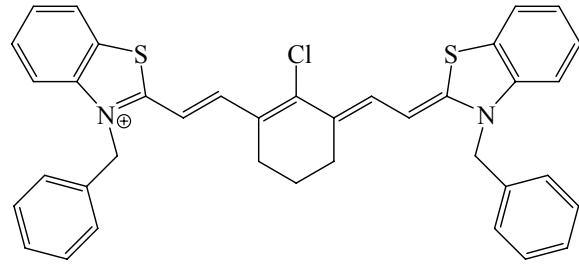

b

Fig. 1. Structures of the AK7-5 (a) and AK7-6 (b) dyes.

\section{RESULTS AND DISCUSSION}

At the first step of study we analysed the emission and excitation spectra of AK7-5 and AK7-6 in an organic solvent and an aqueous solution. Recently, using the absorption spectroscopy technique we have found that both the above dyes can form non-fluorescing $\mathrm{H}$-aggregates in an aqueous solution, but tend to disaggregate in the presence of protein [42]. In an organic solvent, DMSO, AK7-5 and AK7-6 monomers display fluorescence emission maxima at 835 and $839 \mathrm{~nm}$, respectively, while fluorescence excitation maxima are observed at $816 \mathrm{~nm}$ for both dyes (Fig. 2). In the sodium-phosphate buffer solution the examined dyes have the emission maxima similar to DMSO, but there were no bands corresponding to H-dimers or H-aggregates, suggesting that such kinds of aggregates are non-fluorescent. Notably, this observation is in concert with the literature data [43].

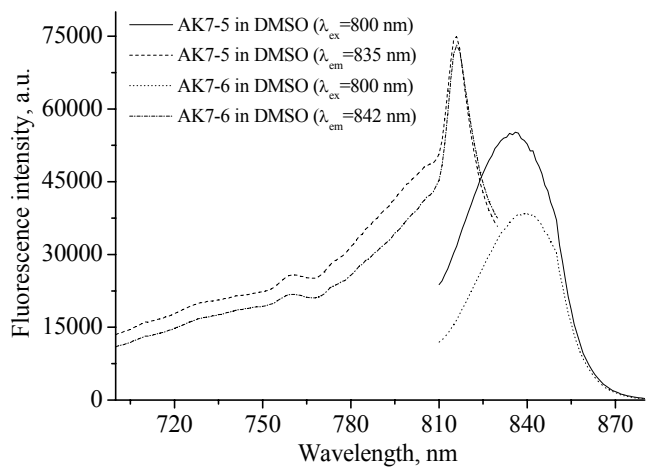

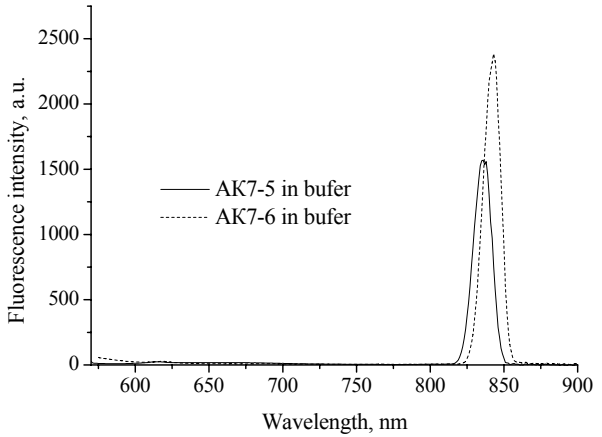

$\mathrm{b}$

Fig. 2. Emission and excitation spectra of AK7-5 and AK7-6

a) in DMSO, b) in sodium-phosphate buffer. The concentrations of AK7-5 and AK7-6 were 14.4 and 9.8 $\mu \mathrm{M}$, respectively

The monomeric peaks of AK7-5 and AK7-6 gradually increased upon the dye titration with the native lysozyme, but above a certain protein concentration the fluorescence intensity reduced to a nearly initial level. This process was accompanied by the appearance of a hypsochromic band at $700 \mathrm{~nm}$ whose intensity increased with the protein concentration (Figs. 3a, 4a).

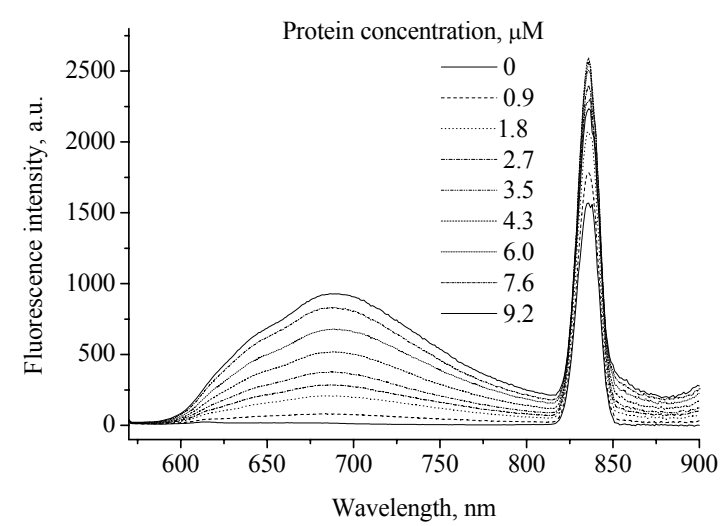

a

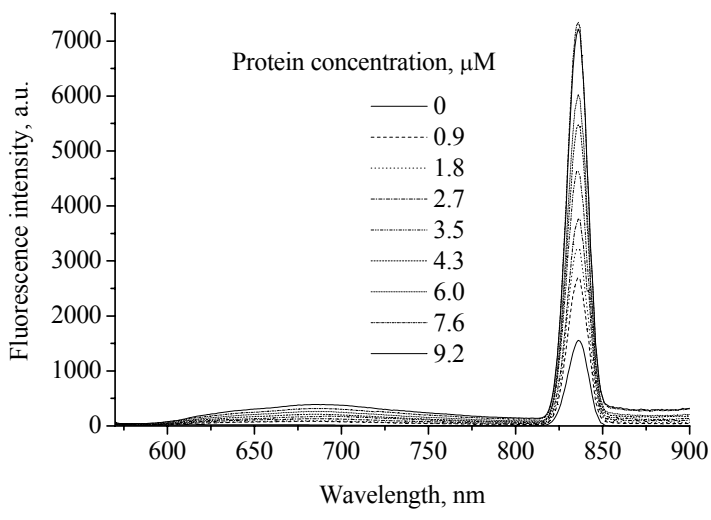

b

Fig. 3. Fluorescence spectra of AK7-5

a) at the increasing concentration of the native lysozyme, b) at the increasing concentration of fibrillar lysozyme The dye concentration was $14.4 \mu \mathrm{M}$. The excitation wavelength was $557 \mathrm{~nm}$. 
In the presence of lysozyme fibrils, both heptamethine dyes demonstrated significant rise of monomeric bands (by a factor of 4.5/3 for AK7-5/AK7-6, respectively) without any decrease of the hypsochromic bands and their slight enhancement compared to the native protein (Figs 3b,4b).

By and large, the rise in the fluorescence intensity of monomer band can be caused by the two processes: i) the growth of the monomer concentration due to a shift of equilibrium between the different dyes forms in the buffer after addition of the protein, as was previously demonstrated using absorption spectroscopy [42]; ii) increase of the dye quantum yield arising from its immobilization on the protein binding site. The interference between these processes complicates the quantitative analysis of the obtained results. Taking into account the absorption spectroscopy data [42] it can be assumed that the emission band of 600-800 $\mathrm{nm}$ corresponds to the H-dimers and H-aggregates of the examined dyes. This finding is especially interesting because, as mentioned above, in an aqueous media H-dimers and Haggregates are commonly uncapable of fluorescing. Allowing for this fact, it can be supposed that the binding of $\mathrm{H}-$ aggregates to the native or fibrillar protein is followed by the changes in the geometric characteristics and electronic structure of $\mathrm{H}$-dimers and $\mathrm{H}$-aggregates of cyanine dyes, thereby causing an increase in the fluorescence quantum yield.

Remarkably, such an unexpected fluorescence was previously observed for the H-aggregates of thiazole orange and merocyanine dyes [44,45]. It is also noteworthy that the intensity of this hypsochromic band in the presence of the native protein was $1.5-2.5$-fold higher compared to the lysozyme fibrils.

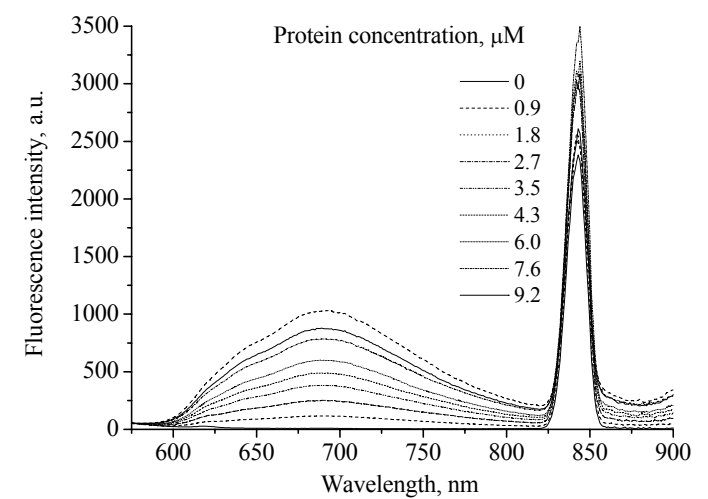

a

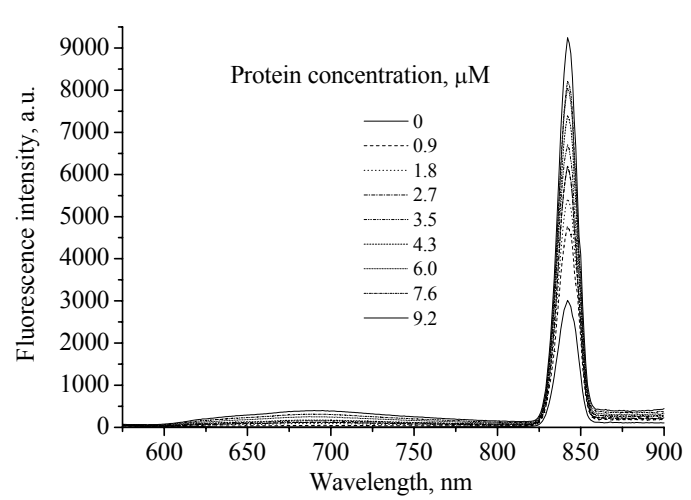

b

Fig. 4. Fluorescence spectra of AK7-6

a) at the increasing concentration of the native lysozyme, b) at the increasing concentration of fibrillar lysozyme

The dye concentration was $4.9 \mu \mathrm{M}$. The excitation wavelength was $561 \mathrm{~nm}$.

Qualitatively, this finding can be rationalized by: i) the formation of the complexes "monomer-protein", "dimerprotein", "H-aggregate-protein" shifting the monomer-aggregate equilibrium; ii) the binding of the dye monomers, Hdimers and $\mathrm{H}$-aggregates to the native and fibrillar lysozyme manifesting itself in the changes in the fluorescence spectra. The fact that the more significant increase of the hypsochromic band 600-800 nm was found for LzN, suggest that the native protein has more binding sites for cyanine aggregates than LzF. Presumably, the hydrophobic, electrostatic, and van der Waals interactions between the dye monomers and the native protein promote the formation of the dye dimers and H-aggregates. The electrostatic interactions between the positively charged molecules of AK75/AK7-6 and negatively charged lysozyme cavities increase the dye-protein affinity. At the same time, despite the LzF has more exposed hydrophobic residues compared to LzN, the contribution of hydrophobic interactions to the formation of the complexes "H-dimer-protein" and "H-aggregate-protein" is less than that of electrostatic forces. It can also be noted that LzF produced a significant increase in the monomeric peak and much less pronounced rise in the peak at 700 $\mathrm{nm}$ compared to LzN. The observed substantial fluorescence increase at $840 \mathrm{~nm}$ can be regarded as an unambiguous proof of specific binding of the dye monomers to lysozyme fibrils.

\section{CONCLUSIONS}

- Both the monomeric and aggregated forms of the novel heptamethine cyanines, AK7-5 and AK7-6, can bind to lysozyme, but the concomitant changes in the electronic structure of H-aggregates render them capable of fluorescing. The growth of the hypsochromic bands with negligible changes of the monomeric peaks induced by the native protein and the opposite effects brought about by the lysozyme fibrils suggest that the native lysozyme has more binding sites for the dye aggregates than fibrillar protein, while the fibril grooves represent specific binding site for the dyes monomers.

- The changes of the monomer band observed in the presence of the native lysozyme is indicative of the disassembly of the H-aggregates in solution followed by their assembly with presumably modified properties on the protein surface. At the same time, the fluorescence intensity of monomeric dyes gradually increases with the concentration of lysozyme fibrils without any re-assembly of the H-aggregates within the fibril structure. 
- Cumulatively, the revealed spectral behavior of the cyanine dyes, viz. significant distinctions in the fluorescence spectra in the presence of monomeric and fibrillar forms of lysozyme, point to the possibility of using these compounds as fluorescent amyloid markers along with the classical amyloid marker Thioflavin $\mathrm{T}$.

\section{ACKNOWLEDGEMENTS}

This work was supported by the grant № 0116U000937 for Young Scientists from the Ministry of Science and Education of Ukraine.

\section{REFERENCES}

1. Dobson C. M. The Amyloid Phenomenon and Its Links with Human Disease // Cold Spring Harb Perspect Bio 2017. - Vol. 9. P. 1-14.

2. Rochet J.C., Lansbury P.T.Jr. Amyloid fibrillogenesis: themes and variations // Curr. Opin. Struct. Biol. - 2000. - Vol.10. P. 60-68.

3. Nelson R. Eisenberg D. Recent atomic models of amyloid fibril structure // Adv. Protein Chem. - 2006. - Vol. 73. P. 235-282.

4. Adamcik J. Mezzenga R. Proteins Fibrils from a Polymer Physics Perspective // Macromolecules. - 2012. - Vol. 45. P. $1137-1150$.

5. Groenning M. Binding mode of Thioflavin $\mathrm{T}$ and other molecular probes in the context of amyloid fibrils - current status // J. Chem. Biol. - 2010. - Vol. 3. - P. 1-18.

6. LeVine H. 3rd. Thioflavine T interaction with synthetic Alzheimer's disease beta_amyloid peptides: detection of amyloid aggregation in solution // Protein Sci. - 1993. - Vol. 2. - P. 404-410.

7. Klunk W.E., Pettegrew J.W., Abraham D.J. Quantitative evaluation of Congo Red binding to amyloid-like proteins with a beta_pleated sheet conformation // J. Histochem. Cytochem. - 1989. - Vol. 37. - P. 1273-1281.

8. Naiki H., Higuchi K., Hosokawa M., Takeda T. Fluorometric determination of amyloid fibrils in vitro using the fluorescent dye, thioflavin T1 // Anal. Biochem. - 1989. - Vol. 177. - P. 244-249.

9. Westermark G.T., Johnson K.H., Westermark P. Staining methods for identification of amyloid in tissue // Methods Enzymol. 1999. - Vol. 309. - P. 3-25.

10. Glenner G.G., Page D.L., Eanes E.D. The relation of the properties of congo red-stained amyloid fibrils to the $\beta$-conformation // J. Histochem. Cytochem. - 1972. - Vol. 20. - P. 821-826.

11. Vus K., Trusova V., Gorbenko G., Sood R., Kinnunen P. ThioflavinT derivatives for the characterization of insulin and lysozyme amyloid fibrils in vitro: fluorescence and quantum-chemical studies // J. Luminesc. - 2015. - Vol. 159. - P. $284-293$.

12. LeVine H. 3rd. Thioflavine $T$ interaction with synthetic Alzheimer's disease beta-amyloid peptides: detection of amyloid aggregation in solution // Protein Sci. - 199. - Vol. 2. - P. 404-410.

13. Nilsson M.R. Techniques to study amyloid fibril formation in vitro // Methods. - 2004. - Vol. 34. - P. 151-160.

14. Murakami K., Irie K., Morimoto A., Ohigashi H., Shindo M., Nagao M., Shimizu T. and Shirasawa T. Neurotoxicity and physicochemical properties of Abeta mutant peptides from cerebral amyloid angiopathy: implication for the pathogenesis of cerebral amyloid angiopathy and Alzheimer's disease // J. Biol. Chem. - 2003. - Vol. 278. - P. 46179-46187.

15. Khurana R., Uversky V.N., Nielsen L., Fink A.L. Is Congo red an amyloid_specific dye? // J. Biol. Chem. - 2001. - Vol. 276. P. 22715-22721.

16. Gadjev N. I., Deligeorgiev T. G. Kim S. H. Preparation of monomethine cyanine dyes as noncovalent labels for nucleic acids // Dyes Pigm. - 1999. - Vol. 40. - P. 181-186.

17. Waggoner A.S., Wang C.H., Tolles R.L. Mechanism of potential-dependent light absorption changes of lipid bilayer membranes in the presence of cyanine and oxonol dyes // J. Membr. Biol. - 1977. - Vol. 33. - P. 109-140.

18. Patonay G., Kim J.S., Kodagahally R., Strekowski L. Spectroscopic study of a novel bis(heptamethine cyanine) dye and its interaction with human serum albumin //Appl. Spectrosc. - 2005. - Vol. 59. - P. 682-690.

19. Kurutos A., Ryzhova O., Trusova V., Tarabara U., Gorbenko G., Gadjev N., Deligeorgiev T. Novel asymmetric monomethine cyanine dyes derived from sulfobetaine benzothiazolium moiety as potential fluorescent dyes for non-covalent labeling of DNA // Dyes and Pigments. - 2016. - Vol. 130. - P. 122-128.

20. Fabian J., Nakazumi H., Matsuoka M. Near-infrared absorbing dyes // Chem. Rev. - 1992. - Vol. 92. - P. 1197-1226.

21. Berlepsch H., Brandenburg E., Koksch B., BoËttcher Peptide adsorption to cyanine dye aggregates revealed by cryotransmission electron microscopy // C. Langmuir. - 2010. - Vol. 26. - P. 11452-11460.

22. Guo M., Diao P., Ren Y.-J., Meng F., Tian H., Cai S.-M. Photoelectrochemical studies of nanocrystalline TiO2 co-sensitized by novel cyanine dyes // Sol. Energy Mater. Sol. Cells. - 2005. - Vol. 88. - P. 33-35.

23. Welder F., Paul B., Nakazumi H., Yagi S., Colyer C. L. Symmetric and asymmetric squarylium dyes as noncovalent protein labels: a study by fluorimetry and capillary electrophoresis // J. Chromatogr. B: Anal. Technol. Biomed. Life Sci. - 2003. - Vol. 793. - P. 93-105.

24. Yarmoluk S.M., Kovalska V.B., Volkova K.D. Optimized dyes for protein and nucleic acid detection // Adv. Fluor. Report. Chem. Biol. III. - 2011. - Vol. 113. - P. 161-199.

25. Mishra A., Behera R.K., Behera P.K., Mishra B.K., Behera G.B. Cyanines during the 1990s: a review // Chem. Rev. - 2000. Vol. 100. - P. 1973-2011.

26. Lou Z., Li P., Han K. Redox-responsive fluorescent probes with different design strategies // Acc. Chem. Res. - 2015. Vol. 48. - P. 1358-1368.

27. Yu F., Li P., Li G., Zhao G., Chu T., Han K. A near-IR reversible fluorescent probe modulated by selenium for monitoring peroxynitrite and imaging in living cells // J. Am. Chem. Soc. - 2011. - Vol. 133. - P. 11030-11033.

28. Sabate R., Estelrich Pinacyanol as effective probe of fibrillar $\beta$ - amyloid peptide: Comparative study with Congo Red // J. Biopolymers. - 2003. - Vol. 72. - P. 455-463. 
29. Volkova K.D., Kovalska V.B., Balanda A.O., Losytskyy M.Y., Golub A.G., Vermeij R.J., Subramaniam V., Tolmachev O.I., Yarmoluk S.M. Specific fluorescent detection of fibrillar $\alpha$-synuclein using mono-and trimethine cyanine dyes // Bioorg. Med. Chem. - 2008. - Vol. 16. - P. 1452-1459.

30. Chegaev K., Federico A., Marini E., Rolando B., Fruttero R., Morbin M., Rossi G., Fugnanesi V., Bastone A., Salmona M., Badiola N.B., Gasparini L., Cocco S., Ripoli C., Grassi C., Gasco A. NO-donor thiacarbocyanines as multifunctional agents for Alzheimer's disease // Bioorg. Med. Chem. - 2015. - Vol. 23. - P. 4688-4698.

31. Volkova K.D., Kovalska V.B., Inshin D., Slominskii Y.L., Tolmachev O.I., Yarmoluk S.M. Novel fluorescent trimethine cyanine dye 7519 for amyloid fibril inhibition assay // Biotech. Histochem. - 2011. - Vol. - P. 86, 188-191.

32. Yang W., Wong Y., Ng O.T.W., Bai B.L.-P., Kwong D.W.J., Ke Y., Jiang Z.-H., Li H.-W., Yung K.L.K., Wong M.S. Novel fluorescent trimethine cyanine dye 7519 for amyloid fibril inhibition assay // Angew. Chem., Int. Ed. - 2012. - Vol. 51. P. 1804-1810.

33. Kovalska V.B., Losytskyy M.Y., Tolmachev O.I., Slominskii Y.L., Segers-Nolten G.M., Subramaniam V., Yarmoluk S.M. Triand pentamethine cyanine dyes for fluorescent detection of $\alpha$-synuclein oligomeric aggregates // J. Fluoresc. - 2012. - Vol. 22. - P. 1441-1448.

34. Johansson M.K., Fidder H., Dick D., Cook R.M. Intramolecular dimers: a new strategy to fluorescence quenching in duallabeled oligonucleotide probes // J. Am. Chem. Soc. - 2002. - Vol. 124. - P. 6950-6956.

35. Khairutdinov R.F., Serpone N. Photophysics of cyanine dyes: Subnanosecond relaxation dynamics in monomers, dimers, and H-and J-aggregates in solution // J. Phys. Chem. B. - 1997. - Vol. 101. - P. 2602-2610.

36. Eisfeld A., Briggs K.J.S. The J-and H-bands of organic dye aggregates // Chem. Phys. - 2006. - Vol. 324. - P. $376-384$.

37. Kasha M., Rawls H.R., Ashraf El-Bayoumi M. The exciton model in molecular spectroscopy // Pure Appl. Chem. - 1965. Vol. 11. -P. 371-392.

38. Kim J.S., Kodagahally R., Strekowski L., Patonay G. A study of intramolecular H-complexes of novel bis (heptamethine cyanine) dyes // Talanta. - 2005. - Vol. 67. - P. 947-954.

39. Ishchenko A.A. Structure and spectral-luminescent properties of polymethine dyes // Russ. Chem. Rev. - 1991. - Vol. 60. P. $865-884$

40. Dumoulin M, Canet D., Last A.M., Pardon E., Archer D.B., Muyldermans S., Wyns L., Matagne A., Robinson C.V., Redfield C., Dobson C.M. Reduced Global Cooperativity is a Common Feature Underlying the Amyloidogenicity of Pathogenic Lysozyme Mutations // J. Mol. Biol. - 2005. - Vol. 346. - P. 773-788

41. Kurutos A., Ryzhova O., Tarabara U., Trusova V., Gorbenko G., Gadjev N., Deligeorgiev T. Novel synthetic approach to nearinfrared heptamethine cyanine dyes and spectroscopic characterization in presence of biological molecules // J. Photochem. Photobiol., A. - 2016. - Vol. 328. - P. 87-96.

42. Vus K., Tarabara U., Kurutos A., Ryzhova O., Gorbenko G., Trusova V., Gadjev N., Deligeorgiev T. Aggregation behavior of novel heptamethine cyanine dyes upon their binding to native and fibrillar lysozyme // Mol. BioSyst. - 2017. - Vol. 13. - P. 970-980.

43. Beckford G., Owens E.A., Henary M.M., Patonay G. The solvatochromic effects of side chain substitution on the binding interaction of novel tricarbocyanine dyes with human serum albumin // Talanta. - 2012. - Vol. 92. - P. 45-52.

44. Lau V., Heyne B. Calix[4]arene sulfonate as a template for forming fluorescent thiazole orange $\mathrm{H}$-aggregates // Chem. Commun. - 2010. - Vol. 46. - P. 3595-3597.

45. Rosch U., Yao S., Wortmann R., Wurthner F. Fluorescent H-aggregates of merocyanine dyes // Ange. Chem. Int. Ed. - 2006. Vol. 45. - P. $7026-7030$ 